\title{
Aşk Örüntüleri Üzerine Bir Anlatı Analizi
}

\author{
A Narrative Analysis on Love Patterns
}

\section{Öğr. Grv. Ozan Uştuk}

\section{Öz}

Aşk, yaşamın her anında gündelik hayatımızı şekillendiren önemli bir etmen/güç olarak karşımıza çıkar. Evrimsel psikoloji alanındaki çalışmaların, aşkın güçlü ve dönüştürücü doğasina hak ettiği önemi göstermesine karşın bu duyguyu anlamaya (verstehen) yönelik antropolojik veya sosyolojik çalş̧malarm eksikliği kendisini göstermektedir. Literatürdeki bu eksiklikten hareketle aşk olgusu, yetişkin/yaşlı (40-70 yaş), genç yetişkin (18-25 yaş) ve gençler (14-18) olmak üzere üç ayrı nesilden görüşmecilerden toplanılan anlatıların analiz edilmesi ve yorumlanması yoluyla incelenmiştir. Antropoloji literatüründeki eksiklik nedeniyle aşka dair kültür temelli incelemeleri olan psikolog Robert Sternberg'in 'aşk üçgeni' (love triangle) teorisinden hareket edilmiştir. Sternberg'in (1986) tanımıyla aşk; yakınlık, bağlllık ve tutku olarak üç bileşen çerçevesinde operasyonalize edilmiștir.

Çalışmada aşkın, biyolojik temelleri inkar edilmeksizin kültürel bir olgu olduğu varsayımından yola çıkılmıştır. Yapılan gözlemler, her neslin aşk tipolojilerinde bir örüntü bulunduğunu göstermiştir. Nesillere özgü aşk tiplerinin, bireylerin içerisinde bulundukları yaş gruplarının sosyal ve kültürel kökenli ihtiyaçlarına göre değiştiği görülmüsstür. Buradan hareketle aşk deneyiminin kültürel değişime bağh olarak, nesiller arasında farklılaşacağı öngörülmüştür. Aşkin doğasındaki bu değişimin, bireylerin faklı yaşam dönemleri içerisinde meydana gelen ihtiyaçlarına paralel bir biçimde değişim gösterdiği için aşk deneyiminin, bireylerin ihtiyaçları temelinde değiştiği şseklinde yorumlanmıştır.

Anahtar Kelimeler: Aşk, Nesil Farkı, Değgişim, Kültür Örüntüleri, Anlatı Analizi

\begin{abstract}
In everyday life, love is an important factor/force shaping our lives. There is a scarcity in anthropological and sociological studies focusing on understanding this emotion even though evolutionary psychology states the strong and transformative nature of love. Moving from the lack of studies, the phenomenon of love is studied by analyzing and interpreting narratives collected from participants of three different generations clustered as adults/elder people (aged 40-70), young adults (aged 18-25) and adolescents (aged 14-18).
\end{abstract}

Due to lack of literature about love in the field of anthropology, this study has been based on the love triangle theory' of psychologist Robert Sternberg, who also interested in cultural aspects of love. Sternberg (1986) operationalize love regarding it as having three main components: intimacy, commitment and passion.

Not neglecting its biological characteristics, the study presumes love as a cultural phenomenon. It is observed that these components may vary in intimate relationships and these variations are closely related to different generations. Moving from this observation, the variation of love experience is interpreted based on the narratives collected from the participants. It is discovered that there are different love patterns among each generation. It is also observed that these love typologies are closely related to the social and cultural requirements of the age group to which the participants belong. This is why, it is presumed that the experience of love may vary among generations depending on cultural differences. Since the nature of love changes between different age stages, it is suggested that the experience of love changes according to the individual's needs.

Keywords: Love, Generation Difference, Change, Culture Patterns, Narrative Analysis

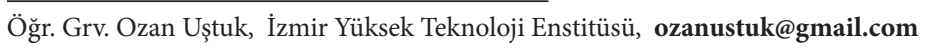




\section{Giriş}

Doğal bir olgu olarak varsayılan aşk, başta psikoloji olmak üzere çeşitli disiplinler tarafından, çeşitli perspektiflerden incelenmiştir. Aşk olgusuna yönelik ilgi belki de aşkın, mutlulukların ve acıların en yoğun/ derin olanlarını deneyimlememize imkan tanımasından kaynaklanmaktadır. Aşk hem başımızı yastıktan kaldırmak için hem de hayatımıza son vermek için bir sebep olabilir.

Başkalarının aşk deneyimlerine dair gözlemlerimiz ve kitle iletişim araçlarından edindiğimiz bilgiler ile aşkın evrenselliğine sorgulamaksızın inanmış durumdayız. Ayrıca bazı antropologlar, romantik aşk için gerekli beyin kimyasının aşkın evrenselliğini kanıtladığını ileri sürerken aşk olgusuna dair algımızın kültürel normlar ile şekillendirildiğini de göz ardı etmemektedirler (Fisher, 1992). Barusch'a (2008) göre biz insanlar aşk için biyolojik olarak donatılmış durumdayız. Ancak kültürel boyutundan ötürü, aşkın tanımında çok az düşünür ve bilim insanı hemfikir olabilmektedir.

Ancak kültürler arası yapılmış birçok antropolojik araştırma (Doherty ve diğerleri, 1994; Dion ve Dion, 1993; Lalonde ve diğerleri, 2004; Kim ve Hatfield, 2004; Naidoo ve Davis, 1988) bize aşkın evrensel ve doğal bir fenomen olmaktan öte kültürden etkilenen ve kültürü etkileyen bir üretim süreci olduğunu göstermektedir.

$\mathrm{Bu}$ makalenin amacı, aşk ilişkilerinin nesiller arasında meydana getirdiği kültürel örüntüleri açığa çıarmak ve bu örüntülerin meydana gelmesinde ne gibi faktörlerin yer aldığını anlayabilmektir. Bu çalışmada, 2012 yılında İzmir ilinde yapılan "Benlik ve Duygu Kavramları Bağlamında Yakın İkili İlişkiler Üzerine Bir İnceleme" isimli araştırmadaki verilerin bir bölümü değerlendirilecektir. Psikolojik Antropoloji yaklaşımının benimsendiği araştırmada aşk olgusunun bütüncül bir incelemesi amaçlanmıştır. Bununla birlikte araştırmanın kapsamı geniş olduğu için, bu çalışmada yalnızca bireylerin nesil farklılıklarından kaynaklanan ihtiyaçları bağlamında değişen aşk örüntüleri örneklem grubu dahilinde betimlenecektir.

\section{Kuramsal Çerçeve}

Aşk olgusu ilgi çekici doğasına rağmen bilim dünyasının, özellikle de antropolojinin pek ilgisini çekmemiştir. Antropolog Leonard Plotnicov'a göre antropologlar, yıllardır romantik aşkın modern Batı'ya özgü olduğunu varsaydılar. Hatta antropologlar alan araştırmasında aşk olgusuna rastlamalarına rağmen, bunu ender olarak dile getirmişlerdir (akt: Goleman, 1992). Jankowiak’a göre araştırmalarda aşkın göz ardı edilmesinin sebebi, toplumbilimcilerin aşk1 insan hayatının lüks bir yönü olduğunu, zor yaşam koşullarında aşkın gelişme şansının az olduğuna inanmalarıydı. Ayrıca aşkın köylüler için değil yönetici sınıfı için var olduğuna dair inanç da bu görüşleri desteklemiştir (Goleman, 1992).

$\mathrm{Bu}$ nedenlerle, aşk konusu, antropoloji disiplini içerisinde kendisine uzun zaman bir yer bulamamıştır. Daha çok psikoloji literatürü içerisinde kendisine yer bulan aşk olgusunun incelenmesinin iki amaç etrafında şekillendiğini görmekteyiz: (a) herkesin anlad1$\breve{g} 1$ anlamıyla aşkın anlamı ve (b) aşk kelimesi ile ifade edilen fenomene bilimsel bir kavramsal çerçeve sağlamak (Fehr ve Russell, 1991).

Bu çalışmada, psikolog Robert Sternberg'in (1986) Aşk Üçgeni' (Love Triangule) teorisi konuya hangi perspektiften bakılacağını belirlemiştir. Bu teoriye göre aşk, yakınlık (intimacy), ihtiras (passion) ve bağlılıktır (commitment) olmak üzere üç unsurdan meydana gelir. Bu üç unsuru eşzamanlı olarak barındıran aşk, bütünleşmiş aşk (consummate) olarak olarak görülse de, Sternberg bu tip aşka nadiren rastlandığı belirtmiştir. İlişkilerde genellikle üç unsurdan ikisinin baskın bir biçimde barındığını gözlemlemiştir.

$\mathrm{Bu}$ ikili unsurların bir araya gelmesi ile bugün sıkça duymakta olduğumuz aşk tipolojileri meydana gelmektedir. Bütünleşmiş aşktan (consummate love) farklı olarak, yakınlık ve bağlılığın birleşimi ile oluşan şefkatli aşk (compasionate love), ihtiras ve adanmışlığın birleşiminden meydana gelen tutkulu/aptalca aşk (fatuous love) ve yakınlık ve ihtiras ile ortaya çıkan romantik aşk (romantic love) olarak üç temel biçim görülmektedir. Bu biçimlerin yanı sıra bu üç unsurun tek tek mevcut olduğu ilişkilerin de olmasına rağmen, bunlar başlı başına bir aşk tipi olarak kabul edilmezler. Sadece adanmışlık boş aşk (empty 
love), sadece tutku karasevda (infautation) ve sadece yakınlık unsurunun barınması hali de hoşlanma (liking) olarak adlandırılır.

Sternberg, daha sonraki çalışmalarında (2002) aşkın niceliksel incelemelerinin verimsiz olduğuna kanaat getirerek, aşkı hikayeler üzerinden incelemeye başlamıştır. Sternberg'e göre aşk hikayeleri çeşitli temalar içerisinde gruplanabilir. Genellikle göze çarpmasa da, üzerimizde kültürel açıdan kabul edilebilir öyküler yaratmamız yolunda bir baskı vardır. İnsanların -örneğin, zina ile ilgili- bir öykü dolayısıyla herhangi bir zamanda ve yerde idam edilmeleri mümkündür, öte yandan bir başka zaman ve yerde böyle bir öykü karşısında kimsenin kılı bile kıpırdamayabilir (Sternberg, 2002, s. 46).

Kültürel açıdan kabul edilebilen ve reddedilen öğeler aşkın tanımlanmasının sınırlarını belirlerken, nasıl yaşantılanması gerektiğine dair bir reçete sunar. Böylelikle kültür aşk dediğimiz olguyu şekillendirir ve kendi güncel söylemleri içerisinde yeniden üretir.

$\mathrm{Bu}$ söylemler ve reçeteler tek düze değildir. Nesiller arasında zaman içerisinde değişebilecekleri gibi aynı söylemlere ve kültürel etkilere maruz kalan bireylerin yaş, sınıf ve toplumsal cinsiyet gibi kimlik bileşenlerine göre çeşitlenmekte ve detaylanmaktadır. Böylelikle aşk kültürler arasında farklılaşabileceği gibi nesiller arasında da farklılaşabilir.

Bu çeşitliliği üç farklı etnografik çalışmada görmek mümkündür. Bunlardan ilki Douglas A. Davis ve Susan S. Davis'in (1989), Fas'ta romantizmin kültürel kısıtlamalar altında nasıl yaşantılandığını ve değişim geçirerek var olduğunu resmettikleri "Bir Fas Şehrinde Ergenlik ${ }^{\prime \prime}$ çalışmalarıdır. Davis'ler (1995) romantizmin deneyimlenmesinin cinsiyetler arasinda farklılaştığı, özellikle kadınların eş seçimi hususunda geleneksel cinsiyet rollerine uygun adaylar seçme konusunda sürekli uyarılmaları yolu ile ilişkilerin kültürel kontrole tabi tutulduğunu ortaya koymaktadırlar. $\mathrm{Bu}$ araștırma, Fas'taki genç kızların geliștirdikleri bir tür sosyal sorumluluk duygularının romantizme karşı eğilimlerine de yansıdığını göstermektedir.

İkinci çalışma ise, Lindholm'un tutku ile bağlanma deneyiminin hem Batı hem de Ortadoğu kültürle-

1 Orjinal eser adı "Adolescence in a Moroccan town: Making social sense". rinde köklü bir yere sahip olmasının yanında bu deneyimin nasıl yaşantılandığını anlattığ " "The Islamic Middle East: An Historical Anthropology " (1996) başlıklı eseridir. Batı ve Doğu kültürleri arasındaki farkı Lindholm şöyle özetlemektedir: batıda evlilik ile iç içe geçen aşk deneyimi doğu toplumlarında ayrı ayrı deneyimlenmektedir. Lindholm (1996) aşkı iki kişi arasında yaşanan mahrem bir deneyim, evliliği de aileleri birbirlerine bağlayan işlevsel bir konum olarak tasvir etmekte, böylelikle aşk ve evliliğin farklı deneyimler olduklarını göstermektedir.

Son olarak, Walle (1998) bizlere erkeklerin ilişkilerini karısı ve sevgilileri ile ayırdıkları iki farklı alanda deneyimlediklerini, Pakistan'ın Lahor kentinde yaptığ 1 çalışmalar ile göstermektedir. Bu çalışmada erkeğin sevgilisi ile olan aşk ilişkisinin, erkekliğin kanttlanması için bir araç haline geldiği, öte yandan eşleri ile yaşadıkları ilişkinin akrabalık sistemlerinin sürdürülmesi gibi daha işlevsel sebepler ile yürütüldügüünü aktarılıyor. Bu çalışmanın aşk ile evliliğin birbirlerinden ayrı deneyimler olduğunu ortaya koyması, Lindholm’un (1996) çalışması ile benzerlik göstermektedir.

Bu etnografik çalışmalarda aşk deneyimlerinin, kültürden kültüre farklılaştığı ortaya konmuştur. İlişkilerdeki etkileşimlerin "normları, rolleri, kuralları, gelenekleri, anlayışları ve beklentileri" öncelikle kültür tarafından tanımlanıp aktarıldığı kabul edilir (Berscheid, 1995:531). Toplumsal çevreyi oluşturan insanlar ve içinde yaşanan kültürün cinsiyete ve cinselliğe ilişkin algı, inanç ve değerleri kişi üzerinde önemli bir etkiye sahiptir ki bu da her kültürde farklı şekillerde romantik ilişkilerin yaşanmasına sebep olmaktadır (Bayhan ve Işıtan, 2010).

Kişisel ilişkilerin altında, duyguların sunumundaki kültürel farklılıkların yattığına dair birçok kanıt bulunmaktadır (Planalp ve Fitness, 1999). Gerek aşkın nasıl yaşantılanması gerektiğini gösteren ideal normlar, gerekse de aşkın nasıl deneyimlendiğinin görüldügü aktüel yaşantılar ele alındığında, aslında kültürün, en temel güdülerimizin eşlik ettiği aşk olgusunun inşası, sunumu, deneyimlenmesi ve sergilenmesindeki büyük etkisi görülmektedir.

2 Türkçeye Balkı Şafak tarafından "İslami Ortadoğu: Tarihsel Antropoloji" adıyla çevrildi. 
Bu noktadan hareketle yakın ilişkilerde aşkın bileşenlerinin nasıl değiştiği, bu değişimin de nesiller arasinda nasıl bir örüntüye sahip olduğu, örneklem grubundaki bireylerin anlatıları yoluyla incelenmiştir. Sternberg'in (1986) teorisi araştırmaya şemsiye oluştururken, derinlemesine görüşme sonucunda elde edilen anlatı analizleri ise aşkın bileşenlerinin nesiller arasında meydana getirdiği örüntülerin keşfedilmesi ve değişimin yorumlanması için kullanılmıştır.

\section{Araştırmanın Yöntemi Araştırmanın Amacı}

$\mathrm{Bu}$ çalışmanın amacı, İzmir ilinde belirlenen üç neslin aşk biçimlerinde farklılıklar olup olmadığının araştırılması ve nesiller arasında meydana gelen farklılıkların kültürel yaşamın oluşturduğu koşul ve ihtiyaçlar temelinde nasıl değiştiğini anlayabilmektir.

\section{Alan ve Örneklem \\ $\mathrm{Bu}$ çalışmanın alanı İzmir İl merkezinde bulunan, işyerleri, devlet daireleri ve Ege Üniversitesi kampüs alanı oluşturmaktadır.}

Bireysel seçimlere dayanan şekliyle "aşk", günümüzün kentli, modern yaşam tarzının bir görünümüdür. $\mathrm{Bu}$ nedenle örneklem seçiminde kentli, orta ve orta-üst sosyo-ekonomik kesimden bireyler tercih edilmişlerdir. Amaçlı örnekleme tekniği ile seçilen katılımcılar, üç ayrı gruptan oluşmaktadır: 1. Beyaz yakalı çalışanlar (10 kişi); 2.üniversite öğrencileri (10 kişi); 3.lise öğrencileri (10 kişi). Bu gruplar, aynı zamanda araştırma sorununun üç ayrı yaş kategorisini temsil etmektedirler. 40-70 yaş arasındaki çalışan bireyler, eski nesli; 18-25 yaş arası üniversiteli öğrenciler yeni nesli; 14-18 yaş arası lise çağındaki bireyler ise, en yeni nesli temsil etmektedirler. Yaşlı katılımcılardan, 8 kişi evli (4 çift), 2 kişi bekar; genç yetişkinlerden 10 kişi sevgili (5 çift) ve gençlerden de 4 kişi sevgili (2 çift) ve 6 kişi de yalnızdır.

Araştırmanın örneklemi bir sınıfı temsil etme kaygısindan öte aşk kurgusunun benzer sosyal anlam kategorilerini paylaşan bir sınıfsal homojenite içerisinde görmek için belirlenmiştir.

Aşk kurgusu sınıfsal yapıların getirdiği gündelik yaşam koşullarından etkilenmektedir. Aşk’’n kültürel inşası tam da bu koşulların ürettiği baskılar çerçeve- sinde kurulmaktadır. Bu nedenle örneklem seçiminde maksat, genelleme ya da bir grubun/sınıfin deneyimini temsil etmek değil, benzer sınıfsal baskıları yaşayan nesiller arasında kurgunun nesiller arasında meydana gelen yapısal değişimler nedeniyle nasıl değiştiğini gözlemlemektir.

\section{Veri Toplama Teknikleri ve Çözümleme Yöntemi}

Alan çalışması için İzmir ilinde, orta ve üst-orta SED'den üç nesil belirlenerek derinlemesine görüşmeler yapılmış ve aşk deneyimlerine dair hikayeleri ses kayıt cihazı ile kayıt edilmiştir.

Hikayeler anlatı analizi tekniği ile çözümlenmiştir. Anlatı analizi, karmaşık insan deneyimini tanımlama ve yorumlama amacina hizmet etmektedir. Webster ve Mertova’ya göre insanlar deneyimlerini hikaye formunda şifrelemektedirler (2007:21). Dolayssıyla bu çözümleme yöntemi günlük yaşamda var olan sembolik davranışların ardındaki anlamı ortaya çıkartmak yolunda ilerlemeye olanak tanımıştır.

Ne var ki anlatı analizi bazı sınırlılıklar getirmektedir. Bunlardan ilki, hikayelerin hafızaya dayalı olmasından ötürü tam anlamıyla aktarılıp aktarılamadığ endişesidir. Analiz tekniğinin bir diğer sinırlılığı ise bireylerin ideal normlar çerçevesinde hikayelerini yeniden organize etme ihtimalidir.

Aşk teması barındırdığı yoğun duygusal hatıralar ve kırgınlıklar nedeniyle açıkça sorulan sorular ile derinlemesine incelenmesi zorluklar barındırmaktadır. Bu nedenle hikayelerin analizi yoluyla vaka ve deneyimlerin bütüncül bir resmini ortaya çıkarmak daha kolay ve mümkün olmuştur. Bahsedilen sinırlllıklar, anlatılar üzerinde yapılan derinlemesine görüşmeler ile giderilmeye çalışılmıştır.

Bu çalışmada yer alan alıntılarda erkeklere dair anlatıların kadınlara oranla kısıtlı olması, aşkın kadınların alanına giren bir olgu olarak görülme tehlikesi ve kadınlara özgü olduğu gibi bir önyargıyı üretme riski barındırmaktadır. Erkek katılımcıların anlatılarındaki kısırlığın sebebi, görüşmecilerin aşka dair hissiyatları üzerine konuşmaktan çekinmeleri, yer yer sıkıntı duymaları, belki de kendi duygularına dair bir içe bakış sorunu ya da aktarım zorluğu yaşamaları olabilir. Bu kısırlığın sebepleri katılımcıların ait olduğu kültürel bağlamda yer alan erkekliğe dair cinsiyet rejimlerinde aranmalıdır. Bu problem, aşk ve di- 
ğer duygulara dair çalışmaların erkeklik özelinde ele alınmasının önemine işaret etmektedir. Erkeklerin kendilik anlatılarında duyguların yeri ve özellikle de yoksunluğu, zorlu ancak keșfedilmemiş bir alan olarak gelecek araștırmalarda incelenmelidir.

\section{Anlatıların Çözümlenmesi}

Hikayelerin çözümlenmesi sürecinde iki temel varsayımdan hareket edilmiştir. Bunlardan ilki aşkın bileşenlerinin (yakınlık, tutku, bağllık), her ilişkide farklı biçimlerde bir araya gelebileceği; ikincisi ise bu bileşenlerin yaş, cinsiyet ve öznel deneyimler gibi faktörler nedeniyle farklılık gösterebileceğiydi.

Derinlemesine görüşmeler yapılırken, anlatılar arasında bazı ortak örüntüler (pattern) olduğu görülmüştür. Bu örüntülerin, nesiller arasında ortak paydalar oluşturduğu fark edilmiştir. Bu bağlamda her neslin kendi içerisinde baskın bir tip olarak yaşantılandığı aşk biçimleri olduğu görülmüştür.

Ergenlerde, göze ilk çarpan örüntü, biyolojik cinsel gelişimlerinin paralelinde gerçekleşen toplumsal cinsiyet rollerinin edinilme süreci içinde olduklarıdır. Akran grupları (peer groups) üzerine yapılmış etnografik çalışmalar, çocuk ve ergenlerin büyürken toplumsal cinsiyet temelinde gruplaştıklarını belgelemiştir. Yoğun gözlemler, çocukların kendi cinsiyetinden bireyler ile etkileşimlerinin, erkek veya kadın olmak üzerine kendi aralarında aktif bir biçimde tartışmalarının, toplumsal cinsiyet kimliklerini oluşturma ve toplumsal cinsiyet rollerini tanımlamalarında yardımcı olduğunu ortaya koymuştur (Eder ve diğerleri, 1995). Bu süreç kısmen bilinçli bir kültürlenme sonucunda meydana gelmektedir. Oğlanlar 'erkek olma'nın, kızlar ise 'kadın olma'nın anlamını öğrenir, yorumlar, deneyimler ve benimserler.

Görüşülen gençlerin ilk aşk ilişsilerine dair deneyimleri ile cinsiyet rollerinin edinilmesi birbiriyle örtüşen bir gelişim göstermektedir. Aşk deneyimlerinin ergenlerin cinsiyet rollerinin edinilmesine katkıda bulunduğu görülmüştür. Aşk ilişkilerinin, erkek ve kadın olmaya dair cinsiyet rollerinin inşasına katkıda bulunduğu, hatta kadınlık ve erkekliğe dair ideal davranış örüntüleri sunarak ergenler için bir izlek işlevi gördüğü söylenebilir. Ancak ilk soru ergenlerde 'erkek olmak' ve 'kadın olma'nın hangi deneyimler ve benlik sunumları ile ortaya konulduğu olmuştur. Buradan hareket ile aşk ilişkisi ile erkekliğin nasıl ilişkilendirildiği araştırılmıştır.
Erkek olmanın, ergenler arasında çok sayıda cinsel partner bulmak ile ilişkilendirildiği görülmüştür. Erkekler ile aşk konusunda yapılan görüşmeler sırasında cinsel ilişkilerin sıklığı ile övünmeleri ana tema olmuştur.

Aktif bir cinsel yaşama sahip olmanın, ergenlerin arkadaş grubu içerisinde yüksek bir statü elde etmelerinin ilk koşulu ve benlik sunumları sırasında ilk başvurulan gösterge olduğu görülmektedir. Erkeklerin cinsel partner sayısı ile arkadaş grupları içerisindeki statüleri arasındaki doğrusal ilişkiye paralel olarak kızlar da kendi grupları içerisinde benzer bir hiyerarşi oluşturmaktadır. Çok sayıda cinsel partner bulan, 'popüler' erkekleri elde tutma temasının da kızlar için önem taşıdığı görülmüştür.

Melis (15) "Doruk ile çıkmamı hiç istemiyorlar (ailesi) ama onu çok çekici buluyorum. Ayrica okulda birçok kızın onunla çıktığım için beni kıskandığını biliyorum."

Asl1 (16), "eğer, koluma taktı̆̆ımda diğer kızlar beni kıskanıyorlarsa o ilişkinin gideri var ${ }^{\text {" }}$ demektedir.

Başka bir deyişle, örneklem grubundaki erkekler için çok sayıda cinsel partner bulmak, kızlar içinse kendi akran grupları içerisinde yüksek statü elde etmiş 'cool' erkekleri elde tutmak grup aidiyeti için önem taşımaktadır. Bu nedenle ergenler arasında cinselliğin sadece keşfedilmediği aynı zamanda sosyal ilişkilerin kontrolü için bir araç haline geldiği düşünülmektedir. Bu durum 16 yaşındaki Eylül'ün anlatısında kolaylıkla görülebilir:

"Bir erkek, bir süre sonra sizinle yatmazsa, yatacağ 1 birini bulur. O yüzden onu kaybetmemek için bir bakıma yapmak zorundasin. Ama hemen birlikte olursan da kaybedersin, yeterince bekletmelisin ama aldatılmayı göze alırsan tabi."

Öte yandan aynı sınıftan başka bir kız ise grup içerisindeki statüsünü erkekler gibi skor tutarak ${ }^{4}$ oluşturup, korumaktadır. Özlem (16)

3 'Gideri var' kullanımı ile görüşmeci ilişkinin devamlılığına dair olumlu bir geribildirim aldığını belirtiyor.

4 Skor tutmak terimi cinsel partner sayısının artmasını ifade eden, spor müsabakalarındaki sayıların yazılmasına benzer bir kayıt işlemini ifade etmektedir. 
“Bütün popüler erkekler ile çıktım. (Yanındaki kız arkadaşı ile muzipçe bakışıp gülüşürler). Ama hiçbiri ile bir şey (cinsel ilişki) yapmadım. Beni zorlarsa ayrilırım. Zaten böyle bir şeyi istemiyorum da benim için daha erken. Benden sadece faydalanmalarina asla izin vermem!"

"Daha erken" vurgusu ait olduğu kültürel yapının ideal normları içerisinde kendisinden beklenen cinsel olgunluğa erişmediğine dair inancını ortaya koyarken popülerlik yarışında yine de erkekleri elde edebileceğini göstermek adına onlar ile cinsellik içermeyen, sıkça partner değiştirdiği ilişkiler yaşamaktadır. İlişkisi ideal kültürel normları çiğneme noktasına geldiğinde de yine kendi inisiyatifi ile ilişkiyi bitirerek kontrollü bir şekilde kendisinin 'popüler' erkekleri elde edebilecek yetkinlikte olduğunu ait olduğu gruba ispatlamaktadır. Ayrica kendisini kontrol etmenin de ergen kızlar arasında bir övünç konusu olduğuna birkaç kez rastlanılmıştır.

Sınıf arkadaşı olan iki kızın cinselliğe farklı yaklaşımlara sahip olduğu, popülerlik yarışında Eylül'ün grup beklentilerine uyma yolunu seçtiği, Özlem'in ise kültürel beklentileri ile aktüel grup beklentileri arasinda daha uzlaşmacı bir yol bulduğu görülmektedir. Ancak ilişkilerde cinsellik teması ve bu temaya eşlik eden sosyal kontrol ve grup aidiyeti, ergenler arasında bir örüntü meydana getirmeye devam etmektedir.

$\mathrm{Bu}$ anlatılar bize cinselliğin, yaşanmasa bile sosyal kontrol adına kullanıldığını ve ikili ilişkilerdeki dinamikler üzerinde büyük etkisi olduğunu göstermektedir. Ergenlerin ilişki dinamikleri ve sosyal statülerini etkileyen hatta belirleyen değişken ise cinselliktir. Başka bir deyişle ilişkinin tutku öğesi.

Ergenler arasında, erkeklerin genelde 'aptalca/tutkulu (fautous) aşk'; kızların ise 'romantik aşk' biçimini tercih ettikleri görülmüştür. İki aşk tipinde ortak tema yine ilişkinin cinsellik temelinde var olan tutku bağlamıdır. İster zevk, ister sosyal kontrol için olsun, cinsellik ve tutku ergenlerin ilişkilerindeki hakim temayı oluşturmaktadır. Tutku temasının, hem biyolojik erginleşme hem de kültürel erginleşme ve toplumsal kimlik inşası sürecinde başrolü oynadığı görülmektedir.

İlişkilerdeki ikinci değer verilen öğenin kızlarda yakınlık, erkeklerde ise bağlılık olduğu görülmüştür. Kılar 'bir şeyleri paylaşabildiği yani yakınlık kurabil- dikleri erkekleri tercih ederken, erkekler ise 'yanında dolaştıracakları' yani kendilerine bağlılık sunabilecek ve sosyal ortamlarda çekinmeden ilişkide olduklarını ilan edebilecekleri kızları tercih ettiklerini belirtmişlerdir.

Bu durumda ergenlikte kızlar ve erkeklerin iki farklı aşk tipolojisine eğilimli oldukları söylenebilir. Başka bir deyişle aşkı yaşantılama eğilimleri, cinsiyetler arasinda farkl1lık göstermektedir.

Buradan hareketle, ergenlik döneminde hem biyolojik hem de kültürel sebepler nedeniyle meydana gelen tutku ihtiyacının, incelenen örneklem içerisindeki ergenler arasında bir aşk örüntüsü oluşturduğu sonucuna varılmıştır. Dolayısıyla kültür temelinde ortaya çıkan ve duygusal ihtiyaçlara cevaben gelişen bir ilişki örüntüsünden bahsedebiliriz.

Genç yetişkinlik denildiği zaman, bireylerin yaşamlarının derinden değiştiği bir dönemden bahsetmiş oluyoruz. Bu dönemde yaşam koşullarının dramatik bir biçimde değiştiğini görmekteyiz. Görüşmecilerin tamamı, çeşitli sebepler ile bir şekilde aileleri ile sürdürdükleri yaşamdan ayrıldıklarını belirmiştir.

Aileden ayrilma süreci hem maddi hem de manevi açıdan yaşam koşullarında büyük değişikliklere gebe bir süreçtir. Üniversiteye gitmek, şehir değiştirmek, ailenin yanından ayrılmak, işe girmek, evlilik potansiyeli taşıan hatta evlilik ile sonuçlanan ilişkilere girmek, fiziksel çevrenin yanında sosyal çevrenin de değişimine işaret eder. Her çevresel değişim bir miktar kültürlenmeyi de beraberinde getirmektedir. Yetişkinliğe atılan adımlar gündelik hayatın içerisinde yeni normların belirginleştiği hızlı bir değişime işaret eder.

$\mathrm{Bu}$ değişimde bireyleri en çok etkileyen faktörün ailelerinden kopma süreci olduğu görülmüştür. Bireylerin her ne kadar aile bağlarını sürdürmeye yönelik çabaları devam etse de farklı çevrelerde harcanan zorunlu vaktin miktarındaki artış bu çabaları sekteye uğratmaktadır. Bu durumun doğal bir sonucu olarak birey ile ailesi arasındaki kopma, genç yetişkine verilen duygusal desteğin sekteye uğraması anlamına gelmektedir.

Çiğdem Kağıtçıbaşı (1993), Türkiye’nin büyükşehirlerinde yaşayan aileleri geçiş tipi aile olarak nitelendirir. Bu ailenin özelliği Batılı bireyselci (individualist: 
X kalıbı) ile Doğulu kolektif (collectivist: Z kalıbı) benliğin ideal tipleri arasında bir geçiș niteliği (Y kalibı) olmasıdır. Bu tip ailelerin maddi konularda bağımsızlaştıkları ancak manevi konularda birbirlerine bağlılıklarını sürdürdükleri görülür. Kağıtçıbaşına göre (1993) karşılıklı duygusal bağımlılık, işlevsel karmaşık ailenin önemli değerlerindendir.

Ancak fiziksel ortamın değişmesi aileden çocuğa yönelen duygusal desteğin kesintiye uğramasını kaçınılmaz hale getirmektedir. Bu kesintinin ikame edilmesi için aşk ilişkilerinin, yakınlık öğesine olan ihtiyacın artması ve yakınlık temelinde gelişen romantik ilişki biçimi aldığı düşünülmektedir.

Araştırma bulguları yaşamlarından eksilen yakınlık nedeniyle ilişkilerde aranan en önemli öğenin de yakınlık olmasının birbirleriyle ilişkili bir nedenselliğe sahip olduğuna işaret etmektedir.

İlişkilerdeki destek arayışı kendisini anlatılarda açıkça göstermektedir.

"Zaten biton işle uğraşıyorum, bir de sevgilim olsun diye içimi kasamıcam. Kafa rahatı istiyom artık. Bana destek olcak, kötüyken on tane soru sorcağına 'bir ihtiyacın var mi?' diycek bi adam istiyom!" (Dilek, 22)

Oya (24) eski ilişkisi ile yeni ilişkisini şu şekilde karşılaştırıyor...

"Önerdiğim şeylere "ben onu yapmam. Ben oraya gitmem." diyerek yant veriyordu. Arkadaşlarıma da yeterince zaman ayıramiyor ve onlarla vakit geçiremiyordum. Şu anki sevgilim ise benim o ruh halimden kurtulmama yardımcı oldu. Bana her zaman mantıklı ve son derece rahatlatıcı şekilde moral verdi".

Burada Oyảnın ilişkide aradığı niteliğin destek olduğunu ifade ettiği açıkça görülüyor. Oyảnın hikayelerinin bütününe bakıldığında eski sevgilisinden ayrılmasında ve şimdi birlikte olduğu kişi ile mutlu olmasının ardında destek ve yakınlık unsurlarının büyük etkisi olduğu görülmektedir.

18-25 yaş aralığındaki bireyler, gelecekteki eşlerini bulmayı amaçladıkları bir dönemdedir ve bu amaç kültürel yapı ile de desteklenmektedir. İdeal eş ölçütleri ile ilgili sorularda eşin aile ile uyumu ve ailenin ilişkiye verdiği destek ön plana çımıştır. Örneğin Beliz (17) "Eğer erkek arkadaşım babam ile oturup sohbet edebiliyorsa benim de onayımı alır" demektedir.

Özellikle kadın görüşmecilerde, erkeğin eş potansiyeline sahip olup olmadığı, erkeklerin aileleri ile sağladıkları uyuma göre test edildiği görülmüştür. Kadınların evlilik için erkeğin desteğine ve yakınlık içeren bir biçimde iletişim kurmasına önem verdikleri saptanmıştır. Bu bağlamda yakınlık, 'biz' (aile) ile ötekiler (komşular ve arkadaşlar) arasındaki sınırı çizmekte, dolayısıyla ötekiler ve çevresel şartlar nedeniyle karşılaşılan zorluklarla başa çıkmak için temel bir gereksinim olarak algilanmaktadır. Bu nedenle ilişkideki yakınlık ve destek, geleceğe yapılacak yatırıma dair bir test niteliği taşımaktadır. Bu test aynı zamanda bireyin ailesinden bağımsız bir şekilde yaşamını sürdürebilmesini kanıtlarken, sevgilisinin bu bağımsızlık denemesine verdiği gizli desteği ölçmek biçiminde de okunabilir.

Bağlllığa verilen önemin ise giderek azaldığı görülmektedir. Bunun nedenleri sorgulandığında Oya (24) "uzun vadeli aşk planları yapma hayal perestliği" nden vazgeçtiğini belirtmiştir. "Kör aşkın geçiciliğini gördüğ̈̈"nü söyleyen Damla (23) "eğitimime ve kariyerime verdiği önemin, yaptığım yatırım kalıcı olacak gerisi boş, bir ayrlsan hem tüm emeklerin boşa gidecek hem de onun için vazgeçtiklerine yanacaksin (üzüleceksin). Kendime ne katsam kâr!" demektedir.

Geleceğe ve kendine yatırımın ön plana geçtiği genç yetişkinlikte ve bu durumun aşk ilişkilerinin yaşamlarındaki belirleyici baskısını bir derece azalttığı söylenebilir.

Tutku öğesinin ise ilişkideki önemini koruduğu görülmektedir. Ancak kadınlarda cinselliğin yakınlık ile daha çok ilişkilendirildiği, erkeklerde ise tatmin olunan bir cinsel yaşamın yakınlıktan daha çok vurgulandığı görülmüştür. Ancak cinsiyet ayrımı olmaksızın neredeyse tüm bireyler kendi deneyimlerini anlayıp paylaşabilecekleri bir eş istediklerini söylemiştir. Bu yönelim, bileşenlere verilen önem sırasını değiştirmiştir. Erkekler için önem sıralamasının tut$\mathrm{ku}$, yakınlık ve bağlılık; kadınlarda ise, yakınlık, tutku ve bağlllık olduğu belirlenmiştir.

Bu bağlamda yakınlık ve tutku 18-25 yaş aralığındaki genç yetişkinlerin ilişkilerinde en çok değer ve önem 
verdikleri bileşenler olarak bir örüntü meydana getirmektedir. Bu noktadan hareketle, görüşme yapılan genç yetişkinlerde 'romantik aşk'ın baskın aşk tipi olduğu ve aşk deneyiminin ergenlik dönemine göre değiştiği sonucuna ulaşılmıştır.

Yetişkin bireylerde ise yaşam göreli bir denge içerisinde sürmektedir. Yetişkinlik gerek iş yaşamı, gerekse de aşk ve diğer ilişkilerin bir derece öngörülebilirlik kazandığı, bir yavaşlama dönemidir. Bu grubun paylaştı̆̆ bir ortak özellik de hemen hemen çoğunun çocuklarının bulunmasıdır. Aile içi ilişkilerde yatay etkileşime (eşler arası) dikey etkileşim de (ebeveynçocuk) dahil olmuştur. Çocuğu olmayan iki çiftin de evcil hayvanları olduğu hesaba katılırsa bu dönemi sorumluluk teması etrafında kavramsallaștırabiliriz. Gerek yatay, gerek dikey etkileşimde aile içinde sürekli manevi destek, geçiş tipi işlevsel ailenin en önemli özelliğidir (Kağıtçıbașı, 1993). Ancak sorumluluk baskısının, kendi ve ötekine dair ayrılan zaman tercihi konusunda birtakım gerilimler yarattığı görülmüștür.

Görüşmecilerin tümü kendi arzularının peşinden gitmek (komşularım ile bir kahve içmek, akşamları yatmadan kitap okuyabilmek, bölünmeden dizi izleyebilmek) ile aile içi sorumluluklarını yerine getirmek (çocukların çantasını hazırlamak, akşam yemeğini hazırlamak, ütüyü yetiştirmek gibi, oğluna keyfi kaçtığında destek olmak) arasında kaldıklarını belirtmiştir.

$\mathrm{Bu}$ durum zıt değerli duygular (ambivalence) meydana getirerek bireyleri strese sokmaktadır. Anlatılar bu konuda kadınların genellikle daha sık ikilemde kaldığını erkeklerin ise, hobileri ve arkadaşları ile geçirdikleri "erkek" aktivitelerinin engellenmesi dışında çok fazla ikilemde kalmadıklarını gösteriyor. Kadınların aile içi sorumlulukların çoğunu üstlenmesi, en azından kendilerini daha sorumlu hissettiklerini gözlemlenmiştir.

Yetișkinliğin, ilişkilerin giderek rutinleștiği ve hayatın içerisine gömüldüğü bir dönem olması dikkat çeker. Bireyler iki aşığın dram ve tutku dolu ilişkisinden çok, yoğun bir iş temposunda birbirine destek olan iki meslektaşın ilişkisine benzediği görülür. Dolayısıyla çevresel şartlar ve aileye karşı kültürel yükümlülükler, yetişkin bireylerin birbirlerinden daha fazla destek ve sorumluluk beklemeleri ile sonuçlanmaktadır.
"İnsanlar bir süre sonra evin içinde kardeş gibi olmaya başliyorsun. Çünkü önceliklerin değişiyor. ... Evlilikte yillar içinde, aşk yerini daha çok sorumluluğa bırakmaya başlıyor. Sevgi tabi ki olmazsa olmaz ama daha çok saygiya kaymaya başliyor. Ama elini ilk tuttuğun zamandaki kalp atışın da olmuyor çok özel durumlarda oluyor. Hatta yeri geliyor off!, bu gün görmeyim seni diyorsun" diyor Birgül (41) gülerek.

Tutku öğesinin ilişkideki baskın konumunun giderek azaldığ 1 ve bu azalmanın romantizmi meydana getiren şartlardaki değişim ile başladığı söylenebilir. $\mathrm{Bu}$ değişim genellikle evli çift dinamiğine çocuğun dahil olması ile başlar.

"Deniz (bebekleri) yokken biz Aziz (eşi) ile gezerdik tozardik, el ele tutuşurduk zaman bizimdi, biz birbirimizindik. Deniz doğduktan sonra sevgi bölïndï." Nur (43)

İleri yaşlardaki bireylerin bazı nadir durumlarda yataklarını ve yatak odalarını bile ayırdıklarına dair hikayeler kaydedilmiștir. Bu evrede ilişkide birbirinin "yol arkadaşı" olduklarını ifade etmektedirler. Onlara göre bu yıllar artık tutkulu ilişkinin bittiği ve arkadaşlığın başladığı yıllardır. Tutkunun azalması ve yol arkadaşlı̆̆ temaları hikayelerde ortak bir kültürel bir örüntü olarak karşımıza çıkar ve aşk ilişkilerini şekillendirir.

İzmir'in geçiş tipi aile biçiminde, batı tipi çekirdek aileden farklı olarak, bireylerin arzusunun "özel bir kişi ile ilişkiye girmek" (founding the One) değil, "evli, barklı adam” olmak olduğu gözlemlenmiştir. Kültürel baskılar otuzlarından sonra evli olmayan bireyler için giderek artmaktadır. Kadınlar "evde kalmış" "kız kurusu", erkekler ise "azgin teke", "serseri" ya da "ibne" (homoseksüel erkek) olmak ile suçlanmaktadır. Her iki cinsiyetten bireylerin normsal evlilik düzenine dahil olmadıkları için davetlerden, şirket yemeklerinden mahrum kaldıkları, dışlandıkları, hatta yarışmalara ve çekilişlere katılmaya hak kazanamadıklarından yakındıkları görülmüştür.

Bu bağlamda görüşme yapılan yetișkinlerde ' $b i z$ ' olma baskısının ön plana çıktığı söylenebilir. Bu baskı bir ilişkiye olan "bağlllık" ile ölçülmekte ancak bağllilı̆ın cinsel sadakatten çok evlilik kurumuna bağlılık oldu- 
ğu görülmektedir. Bağlllığın en ideal kültürel biçimi evliliktir. Çünkü eșe sadece sözel değil hukuksal bir bağlılık da gösterilmiş olur. Böylelikle bağlılık faktörünün kültürel kabullere dayanan sosyal ilişkiler aracılığıyla desteklenmesi hatta dayatılması ile aşk kurgusuna bağlllık giderek daha fazla dahil olur. Bireyler kendilerini gerek zorunlu hissederek, gerekse de normu içselleştirerek uyum gösterme eğilimi taşırlar ve ilişkilerde bağlllık boyutu ön plana çıar.

Kültürel baskıların dışında bağlılık boyutunun ön plana çıkmasında bir diğer etmen ise çevresel/yapısal baskılardır. Hane içi yaşamın dengesi, sorumlulukların artması ile eşler arası desteğin kesintisiz devam etmesine bağlıdır. Yetişkinlerin ilişkilerinde istikrar aramalarının sebebi artan sorumluluklara paralel destek ihtiyacının ortaya çıkmasıdır. İstikrar arayıșı bazen kendisini değişime direnç olarak gösterebilmektedir.

"Değiştiremediğim şeyler var. Hem de fazlasıyla. Ama zor. Onlar benim yapımla ilgili, mücadele ediyorum ama zor. Değişen şeylerde var tabi ama karşındakine hitap edecek şsekilde değişsemiyorsun. Öyle bir beklenti oluyor tabi iki tarafta da ama çok mümkün değil. Evlilik zordur." Ahmet (48)

"Bir de ben yapım dolayısıyla memnun olduğum şeyleri hayatıma fazlasiyla sokmaktan memnun oluyorum. Ben bağımlılığa yatkınım. Bir şeyi yaptığımda o şeyi sürdürmeyi seviyorum hele memnunsam emek vermeyi seviyorum. Ailemde de böyleydi." (Aziz, 46)

İlişkilere bağlllığın toplumda evli bir çift olarak yer etmenin bir önkoşulu ve kültürel olarak benimsenen bir örüntü olarak aşk ilişkilerinin niteliğini belirlediği görülmektedir.

Görüşme yapılan yetişkinlere "İdeal ilişki nedir?" sorusuna verdikleri yanıtlardaki ortak paydalar şu şekildedir: bağlllık, yakınlık, birbirinin halinden anlamak, destek olmak, sevildiğini hissetmek, yanında huzurlu hissetmek, arkanı rahatça dönebileceğimi bilmenin rahatlı̆g.

Bu ortak kelimelerin çizdiği tablo yetişkinler arasında ikili ilişkilerin baskın biçiminin, yakınlık ve bağlılığın önem kazandığ 1 şefkatli aşk olduğunu göstermekte- dir. Bu aşk tipolojisi de ilişkilerin kültürel inşaya maruz kaldığını ve nesiller arasında farklılaştığını ortaya koymaktadır.

\section{Sonuç}

$\mathrm{Bu}$ çalışmada, İzmir'de yaşayan üç farklı neslin aşk yaşantıları betimlenmiştir. $\mathrm{Bu}$ betimlemede, yaş gruplarının genel özellikleri, aşka dair kültürel alg1ları, aşk deneyimlerinde hangi öğelere öncelik tanıdıkları, bu tercihlerin hangi aşk tipini deneyimlemelerine yol açtığı, öğelere verilen önceliğin nedenleri ve bireyler için yerine getirdiği işlevleri, cinselliğin aşk yaşantısındaki ve kültürel kabuller içindeki yeri dikkate alınmıştır. Kısaca, aşk olgusunun (yakınlık, tutku, bağlllık bileşenleri çerçevesinde) değişen kültürel koşullar altında bireylerin yaşamlarında nasıl bir görünüm kazandığı betimlenmiştir.

Aşk ilişkilerinin deneyimlenmesi ve ifade biçimlerinde kültürel öğrenmenin paydası açıktır. Ancak bu çalş̧mada dikkat çekilmek istenen esas boyut, kültürel ve sosyal şartların meydana getirdiği yaşam döngüleri içerisinde bireylerin ihtiyaçlarının değişmesi ve aşk ilişkilerinin de bu değişime paralellik göstermesidir.

Bireylerin yaş bağlamında incelendiği üç kesit kültürel olarak yaşanılan büyük değişim ve kırılma dönemlerine denk gelmektedir.

Araştırma kapsamında görüşülen 14-18 yaş aralığındaki ergenlik dönemindeki bireylerde 'tutkulu aşk' örüntüsünün baskın olduğu görülmektedir. Bu dönemde cinsel erginleşme sebebiyle gençlerde meydana gelen biyolojik ihtiyaçlar ve aynı zamanda sosyal kabul ve uyum ihtiyacı nedeniyle hakim olan cinsiyet rollerinin benimsenmesi ilişkilerdeki tutku öğesinin ön plana çıkmasına neden olmaktadır.

18-25 yaş grubundaki bireyler ise sırasıyla iş yaşamına atılma, ailelerinden kopma ve kendileri birer aile kurma aşamalarından geçmektedirler. Bu süreçte aile bağlarının kopmasından kaynaklanan yakınlık ihtiyacının eksikliği kendisini ilişkilerde yakınlık öğesinin önem kazanması ile göstermekte dolayısıyla yaşanan ilişkiler 'romantik aşk' tipine denk gelmektedir. 
40 yaş ve üstü yetişkin grubunda ise uzun süreli ilişkilerin getirdiği sorumluluklar, cinsel yaşamın (tutku öğesinin) ilişkideki önem ve konumunun değișmesine ve bu konuma bağlı olarak ilişkinin de dönüşmesine neden olur. Bu sürece paralel biçimde, çocuklarının büyüyüp evden ayrılmaları ve emeklilik gibi temel değişimler nedeniyle meydana gelen eksiklik çiftler arasında yakınlık ve samimiyetin önemini arttırmaktadır. Dolayısıyla ilişkiler, 'şefkatli aşk' biçiminde yaşantılanmaktadır.

Nesiller arasındaki ikili ilişkilerin değişimini 84 yaşındaki Naciye Anneanne bir deyiş ile özetlemektedir: "Yüz yüze, göt göte, git öte". Bu deyiş ilişkilerde tutku ile başlayan yakınlık ve bağlılık ile devam eden ilişki örüntülerinin halk dilinde yer ettiğini ve kültürel bir söylem olarak üretilmeye devam ettiğini de göstermesi bakımından önemlidir.

Çalışmada tüm bireylerin, kendi sınıfsal yapıları çerçevesinde deneyimledikleri gündelik hayatın dikte ettiği değişim ve kırılma dönemleri nedeniyle eksikliği oluşan psikolojik ihtiyaçlarını gidermeye yönelik ilişkiler yaşadıkları görülmüştür. Bu durum aşk ilişkilerinin, yaşam sürecinde bizi psikolojik yönden destekleme işlevi gösterdiği şeklinde yorumlanmıştır. Bunun yanında aşk ilişkilerine dair açıklamaların, toplumsal şartlar ve kültürel bağlam içerisinde anlamlı bir bütün olarak incelenebileceğine dikkat çekilmiştir.

\section{Kaynakça}

Barusch A. S. (2008). Love Stories of Later Life: A narrative approach to understanding romance. New York: Oxford University.

Bayhan, P., Işıtan, S. (2010). Ergenlik Döneminde İlişkiler: Akran ve romantik ilişkilere genel bakış. Eğitim Kültür ve Araştırma Dergisi, 5 (20), 33-44.

Berscheid, E. (1995). Help Wanted: A grand theorist of interpersonal relationships, sociologist or anthropologist preferred. Journal of Social and Personal Relationships, 12, 529-533.
Davis, D. A. \& Davis, S. S. (1995). Possessed by Love: Gender and Romance in Morocco. In William Jankowiak (Ed.), Romantic Passion: A universal experience? (pp.219-238). New York:Colombia University.

Davis, S. S. \& Davis, D. A. (1989). Adolescence in a Moroccan town: Making social sense. New Brunswick: Rutgers University.

Dion, K. L., Dion, K. K. (1993). Gender and Ethnocultural Comparisons in Styles of Love. Psychology of Woman Quarterly, 17, 463 - 473.

Doherty, R. W., Hatfield, E., Thompson, K. \& Choo, P. (1994). Cultural and ethnic influences on love and attachment. Personal Relationships, 1, 391-398.

Eder, D., Evans, C. C. \& Parker, S. (1995). School talk: Gender and adolescent culture. New Brunswick, NJ Rutgers University Press.

Fehr B., Russell, J. A. (1991). The Concept of Love Viewed From a Prototype Perspective. Journal of Personality and Social Psychology, 60 (3), 425-438.

Fisher, H. (1992). Anatomy of Love: The natural history of monogamy, adultery and divorce. New York: Norton and Co.

Goleman, D. (1992, November 24). After Kinship and Marriage: Anthropology discovers love. The New York Times, p. C1.

Kağıtçıbaşı, Ç., (1993). İnsan Aile ve Toplum, Remzi Kitabevi İstanbul, 2. Basım.

Kim, J., Hatfield, E. (2004). Love Types and Subjective Well-being: A Cross- Cultural Study. Social Behavior and Personality, 32(2), 173-182.

Lalonde, R. N., Hynie, M., Pannu, M., Tatla, S. (2004). The Role of Culture in Interpersonal Relationships : Do second generation south asian canadians want a traditional Partner?. York University Journal of Cross-Cultural Psychology, 35 (5),503-524. 
Lindholm, C. (1996). The Islamic Middle East: An historical anthropology. Oxford: Blackwell.

Naidoo, J. C., Davis, J. C. (1988). Canadian South Asian Women in Transition: A dualistic view of life. Journal of Comparative Family Studies, 19, 311-327.

Planalp, S., Fitness, J. (1999). Thinking/feeling about social and personal relationships. Journal of Social and Personal Relationships, 16, 731-750.

Sternberg, R. J. (1986). A Triangular Theory of Love. Psychological Review, 93, 119-135.
Sternberg, R. J. (2002). Aşk bir Öyküdür. Ank: İmge Kitabevi.

Walle, T. M. (1998). August 13-16), "As Good As a Man Can Be: Some Thoughts on Love, Marriage and Masculinity", Paper Presented at The Fourth Nordic Conference on Middle Eastern Studies, Oslo, Norway.

Webster, L. \& Mertova P. (2007). Using narrative inquiry as a research method: an introduction to using critical event narrative analysis in research on learning and teaching. Abingdon,UK: Routledge Falmer. 